\title{
Threats to Homeland Security: Reassessing the All-Hazards Perspective, 2nd Edition. Ed. by Richard J Kilroy. Hoboken, N.J.: Wiley, 2018.
}

Mark T. Peters

USAF

Follow this and additional works at: https://digitalcommons.usf.edu/jss pp. 93-95

\section{Recommended Citation}

Peters, Mark T.. "Threats to Homeland Security: Reassessing the AllHazards Perspective, 2nd Edition. Ed. by Richard J Kilroy. Hoboken, N.J.: Wiley, 2018.." Journal of Strategic Security 11, no. 3 (2018) : 93-95. DOI: https://doi.org/10.5038/1944-0472.11.3.1704 Available at: https://digitalcommons.usf.edu/jss/vol11/iss3/6

This Book Review is brought to you for free and open access by the Open Access Journals at Digital Commons @ University of South Florida. It has been accepted for inclusion in Journal of Strategic Security by an authorized editor of Digital Commons @ University of South Florida. For more information, please contact digitalcommons@usf.edu. 
Threats to Homeland Security: Reassessing the All-Hazards Perspective, 2nd Edition. Ed. by Richard J Kilroy. Hoboken, N.J.: Wiley, 2018. 
Peters: Book Review: $\triangleleft>>$ Threats to Homeland Security $<j>$

Threats to Homeland Security: Reassessing the All-Hazards Perspective, $2^{\text {nd }}$ Edition. Ed. by Richard J Kilroy. Hoboken, N.J.: Wiley, 2018. ISBN 9781-119-25181-1. Photographs. Questions. Glossary. Sources cited. Index. Pp. xxii, 550. \$115.00.

Richard Kilroy's Threats to Homeland Security: Reassessing the All-Hazards Perspective returns first edition writers while also recruiting several new individuals to contribute their viewpoint. As editor, Dr. Kilroy faced an uphill challenge ensuring the overall theme remained consistent while reorganizing foundational chapters. The book moves forward through advancing a conceptual framework, updating data on actor methodologies and motivations, and delivering a clear picture regarding how homeland security efforts counter those challenges. Brand new chapters include discussions on critical infrastructure, homeland security intelligence, and homeland security planning. All the standard textbook features appear with well-sectioned chapters, key term sidebars, and questions for students, as well as longer, break-out sections highlighting key events and players. Overall, the text delivers an excellent starting place for any instructor teaching first-time, homeland security students.

The difficulties faced when one first encounters the homeland security milieu remain complicated and challenging despite the seventeen plus year history of the modern concept. Dr. Kilroy attempts to introduce each element separately rather than advocating a combined theme even if the subjects are not quite sequential. The text trumpets an all-hazards perspective, which, in practice, means threats to homeland security can sound from a natural disaster, accidental impact, or man-made incident. Although natural disasters and accidental impacts are important, and have widely-ranging effects, the book's major movements focus on intentional, man-made acts committed by known actors. One may divide the text into four, non-sequential, areas addressing what national security means, characterizing actors and their motivations, describing functional enablers, and enumerating current homeland security practices. To adequately achieve homeland security each part must be incorporated into the larger whole. The text's letdown occurs when despite advocating a central theme each writer takes an independent approach to homeland security

The first area and first four chapters define the basic homeland security course building blocks by presenting national security elements and matching the text's all-hazards approach to threat assessment techniques. These initial sections are not unique constructions for experienced homeland security professionals and do establish new students a helpful background. The two security chapters adequately merge longer term U.S. national interests into recent homeland security concerns. In addition, the all-hazards chapter blends well with presented threat matrices to allow adequately segmenting new threats. New analytic and planning tools are welcome to any security researcher and this 
all-hazards set is well worth reviewing. It is unfortunate the time and construction represented through these excellent threat approaches are not consistently applied to deconstructing threats later in the text.

The second topic area, terrorism, appears throughout chapters six, seven, and ten, with the first two chapters covering state and non-state actors while chapter ten discusses domestic terrorism. All three areas are critical to understanding homeland security and the introduction to actors and basic terrorist strategy across these areas hits all notes perfectly, if independently. Applying the all-hazards format and matrices to these three chapters would have improved concept presentation and the overall cohesion between ideas. For example, current homeland security practices suggest domestic terrorism occurs as nonstate actions conducted by one's own citizens, so integrating domestic and non-state chapters in a third edition may be beneficial. State or non-state concepts for terrorism resolve a binary idea with all terrorist actors being one or the other. Perhaps, the domestic terrorism chapter would more appropriately fit as a history of U.S. terrorism. Further, each chapter also discusses countering terrorism without linking proposed strategies to the other terrorism chapters. A more streamlined framework for analyzing and responding to terrorism would better aid homeland security experts in their work to deter, deny, and defeat the many daily threats the U.S. faces.

Functional components form the core of the third area with chapters on cyber options, weapons of mass destruction (WMD), and mass effect enablers. The cyber and WMD sections present clear concept definitions, demonstrating the capabilities and potential challenges associated with each function. Each chapter discusses several components through nuclear, biological, chemical, and radiological and then by cyber-crime, cyberterrorism, and cyber-warfare. The mass effect chapter's labeling sounds slightly distant from functional topics as it deals exclusively with information tools. Social media may have integrated better with the cyber chapter, but a future grouping for these three chapters as a functional unit may help. The text highlights only a few cyber-defense options, however, in all fairness, many whole texts have been published featuring only homeland defense cyber strategies. For example, whole publications from the National Institute for Standards and Testing (NIST) are written regarding cyber-defenses.

The best, and last topic area, homeland security planning, combines chapter five, Critical Infrastructure (CI) with the book's last two chapters on Homeland Security Intelligence, and Homeland Security Planning. While the CI chapter appears early, the integration lack between chapters means holding the material till later in the work does not create a knowledge gap. Perhaps moving the intelligence and planning chapters forward in the book could aid in presenting both background material and potential tools at the beginning. The knowledge presented here depicts the vital parts to how the U.S. government approaches homeland security challenges. Understanding all these concepts initially would aid the 
student comprehending why the various actors and functional components influence individual chapters. The planning discussion is also underrepresented. Planning takes significant study and reams of preparation to conduct appropriately but the text spends only three pages from the overall five hundred in discussing planning techniques. Guidelines do refer to traditional planning processes being well-documented in external sources agencies like theFederal Emergency Management Agency (FEMA) and NIST. One of the biggest flaws in many Homeland Security operations, as presented in side-notes during the text, seems to occur through lacking an understanding of how other government agencies conduct planning, and the book misses a key opportunity to close those loopholes.

Despite the missing coordination between the chapters, Threats to Homeland Security presents excellent notes with exquisite details about each homeland security concept while lacking the overall integration to coordinate the symphony. Using the text to support a class would likely bring Dr. Kilroy's symphony together more effectively for the beginning student. As always, professors often bring static material to life through their own experiences and knowledge. For advanced or experienced homeland security practitioners, the comprehensive references offered herein make this a key component on one's homeland security shelf. As an intelligence and cyber-security professional, my focus is on improving integration and this work, standing on its own, falls a little short. This second edition adds key components to the original and references are well-documented for one to conduct further research. Overall, Dr. Kilroy reached his goal of presenting a comprehensive Homeland security text, and I recommend adding the work to one's reference shelf, or pursuing a class based on this material.

Mark T. Peters II, USAF 